\title{
METHODOLOGICAL FOUNDATIONS FOR MODELING CONTEMPORARY POLITICAL ACTIVISM IN THE DIGITAL AGE
}

\section{Polovyi M. A.}

\section{INTRODUCTION}

Various forms of political activism are becoming more widespread at the modern stage of political development. Detailed research of the manifestations of modern activism, obviously, should include, in addition to their description and explanation, a certain prediction as to the emergence and degree of impact of different forms of activism. In this regard, the methods of mathematical modeling of political processes get special importance, as they form the basis for scientific comprehension of certain processes and for making predictions about these processes. Therefore, the purpose of this paper is to define and analyze some methodological foundations which can lay the basis for modeling of such a contemporary form of political processes as political activism.

\section{Theoretical underpinnings of models' application in the studies of socio-political processes}

The positive aspects of building models with research purposes are well known ${ }^{1}$. Yu. Plotinsky studied in detail, but mainly in the sociological frameworks, the application of different models in relation to social processes ${ }^{2}$. At the same time, there are many theoretical and methodological problems of construction and further application of such models in political studies.

Among the many definitions of the term model, scientific literature has two most common:

- model as an analogue of an object;

- model as a sample ${ }^{3}$.

In our definition of the model, we proceed from a rather traditional scientific understanding of the model as an artificially created object in the form of a scheme, logical and mathematical formulas, in a certain sense

${ }^{1}$ Павловский Ю. Н. Имитационное моделирование. М. : Издательский центр «Академия», 2008 - 240 с.; Моисеев Н.Н. Математика в социальных науках // Математические методы в социологическом исследовании. М., 1981. C.10-24; Easton D. A Systems Analysis of Political Life. New York: Wiley, 1965.

${ }^{2}$ Плотинский Ю.М. Модели социальных процессов : 2-е изд., перераб. и доп. М.: Логос, 2001. 296 с.

${ }^{3}$ Ibid. C. 3. 
similar to the studied object and clearly reflecting its individual features ${ }^{4}$. Therefore, in our opinion, the model of the political process can be defined as an artificially created object in the form of various symbolic constructions, which is similar to the studied process in a certain sense. The task of the model constructing is its research and thus deepening the knowledge about modeled features of the original object.

So, the epistemological essence of constructing the model is a transition from a direct study of the initial phenomenon, process, or technical system to another phenomenon, process, or sign system called model. This transition, in some cases, gives the only possibility to reproduce studied phenomena, facilitates research, makes it fundamentally possible to determine values, processes, and their properties interesting to the researcher.

Thus, the model coarsens, simplifies the original, roughly reflects the studied object but, at the same time, serves as its substitute for the study and, in addition, allows to clearly see individual sides (features) of the original ${ }^{5}$.

However, two conditions must be met: on the one hand, the model must be simple enough to be studied; on the other hand, the model should not be "too simple" or overly simplified. Although the model is in some sense "imperfect" and "rough" compared to the studied phenomenon, one model can be used to describe a wide class of different phenomena.

It should be noted that depending on the tasks of the study different models may be obtained for the same object with the aim to formalize its different functions. The number of these models often depends on the complexity, specification or simplification of the description of the real system ${ }^{6}$. Obviously, the suchlike approach is directly linked with the basic property of reflecting only some features of the original object.

While identifying methodological content needed for the construction of models of political processes, one should also consider the problem of correlation between the model and the theory. According to V. Shtoff, starting from the eighteenth century the model has been considered by scientists as something profoundly different from theory. The theory in this sense means a set of statements about the general laws of a particular field, linked logically together so that certain consequences derive from the original assumptions; then the model is understood as either a) a specific image of the studied object or objects (atom, galaxy, etc.), which reflects its real or predicted properties, structure, and other features of these objects; or b) any other object actually 1988. $506 \mathrm{c}$.

${ }^{4}$ Вартофский М. Модели. Репрезентация и научное понимание. М.: Прогресс,

${ }^{5}$ Кондаков Н.И. Логический словарь-справочник / Отв. ред. Д.П. Горский. М.: Наука, 1975. С. 361.

6 Пащенко Ф.Ф. Введение в состоятельные методы моделирования систем : в 2-х ч. М.: Финансы и статистика, 2006. Ч.1: Математические основы моделирования систем. 328 с. 
existing (or imagined) along with a studied object and similar to it in terms of certain properties or structural features. But no matter how different these two meanings are, they have a common understanding of the model as a certain finite system, a certain unitary object, without distinction whether it exists in reality or only in the imagination. In this sense, the model is not a theory itself but something described by this theory - its unique subject ${ }^{7}$.

Yu. Plotinsky slightly broadens the understanding of the interrelationship between the model and the theory. He rightly pointed out that the concepts of the "model" and the "theory" are interpreted ambiguously by modern scientific literature, the line between them is blurred. At the same time, Yu. Plotinsky stated that the methodology of science recognizes the following interpretation of these concepts:

- The model is a conceptual tool primarily focused on managing a simulated process or phenomenon. Thus the function of prediction and prognostication serves to the purpose of control.

- The theory is more abstract than the model, a conceptual tool whose main purpose is to explain these processes and phenomena. The predictive function of the theory is aimed to explain phenomena ${ }^{8}$.

V. Shtoff thought that an essential feature that in general distinguishes the model from the theory is "not the level of simplification, not the measure of abstractedness and, therefore, not the number of abstractions and distractions achieved, but the way in which these abstractions, simplifications and distractions are typical for the model"9. While the content of the theory is expressed in the form of a set of judgments, linked by the laws of logic and special scientific laws and "directly" reflecting regular, necessary and general connections and relations inherent to reality; the same content in the model is presented in the form of certain typical situations, structures, schemes, collections of idealized (even simplified) objects, in which these regular connections and relations are realized, or in which laws formulated by the theory are implemented in its pure form. Therefore, the model is always a particular concrete construction: visual, finite and accessible for inspection or practical action.

Therefore, if the property to reflect reality (object) in a simplified, abstracted form is common for the theory and the model, the property to implement this reflection in the form of a particular, separate, concrete and, therefore, visual system - is a feature which distinguishes the model from the theory ${ }^{10}$.

\footnotetext{
${ }^{7}$ Штофф В.А. Моделирование и философия. Л.: Наука, 1966. С. 9.

${ }^{8}$ Плотинский Ю.М. Модели социальных процессов. М.: Логос, 2001. С. 87.

${ }^{9}$ Штофф В.А. Моделирование и философия. Л.: Наука, 1966. С. 14.

${ }^{10}$ Ibid. C. $14-15$.
} 
As L. Boiko-Boichuk correctly points out, introducing the methods of modeling from the natural sciences into political science has become possible precisely due to the analogy ${ }^{11}$. According to A. Uyemov, for the first time, the term "analogy" appeared in the Pythagorean school, where it was originally used only for the study of relations between numbers in the meaning of proportionality, proportion ${ }^{12}$. Aristotle understood the analogy as a similarity of relations, proportion ${ }^{13}$. As it follows from A. Uyemov's fundamental work, in our time proportion is treated only as one of the possible types of analogy.

A. Uyemov defined the analogy as one of the types of inference (along with induction and deduction), in which the conclusion relates to a subject other than the one in the premise ${ }^{14}$. After careful analysis of different examples of the use of analogy in the natural sciences, A. Uyemov identified fifty-one types of inference of new knowledge by analogy, including proportional, substantive, and other analogies ${ }^{15}$.

Obviously, an analogy must be characterized by at least two of the following features: firstly, it must be based on a certain (in some sense) similarity of one object and another - in our case these are the model and its original; and, secondly, the essence of the analogy is in the transferring of certain information or knowledge about the properties of one object to another, the one with which the analogy is drawn.

So, it is precisely the analogy between the object of a study - the political process - and the model that reflects its particular features that enables the use of modeling in the study of political processes. Thus, the conclusions drawn about the further state of the model will be transferred to the further state of the modeled object by analogy.

Analogy, as well as other forms of reasoning - induction and deduction - is inextricably linked to a single thought process. It is closely related to them and cannot exist without continuous mutual complement and interaction with other conclusions. The analogy has some cognitive value. The inference process gives probable knowledge, but this probable knowledge carries something new, which helps us to understand the environment and to predict the development of this phenomenon or event. At the same time, no matter how significant the similarity of two things is, conclusions by analogy are always probable ${ }^{16}$.

${ }^{11}$ Бойко-Бойчук Л. Метод аналогій у соціально-політичних дослідженнях. Політичний менеджмент. 2007. № 4. С. 78-80.

12 Уемов А. И. Аналогия в практике научного исследования. М.: Наука, 1970. С. 50.

${ }^{13}$ Ibid.

${ }^{14}$ Ibid. C. 19.

${ }^{15}$ Ibid. C. 46-63.

${ }^{16}$ Кондаков Н.И. Логический словарь-справочник. Отв. ред. Д.П.Горский.М.: Наука, 1975. С. 38. 
In assessing the probability of inference a number of the following conditions should be taken into account:

1) the more general properties of the comparable objects you know, the higher probability for the conclusion by analogy is;

2) the more significant common properties found in the comparable subjects are, the higher the probability is;

3) the deeper mutual logical relationship of similarities is, the more probable and closer to reliability the conclusion is;

4) if the object in respect to which we make the conclusion by analogy has any property incompatible with the property on the existence of which we conclude, then the general similarity is irrelevant ${ }^{17}$.

A. Uyemov added the following rules to this list: 1) general properties should be any properties of the comparable objects, thus they must be selected "without prejudice" against properties of a certain type; 2) the property detected in the model must be of the same type as the general properties of the studied object; 3) the general properties should be as specific as possible for the comparable objects, that is, they should belong to the smallest possible range of objects; 4) the property found in the model, on the contrary, should be the least specific, that is, belong to as many objects as possible ${ }^{18}$.

A. Uyemov also noted that there are characteristics common to all types of conclusions by analogy. In particular, in all cases, one subject is put to direct investigation, while the conclusion is drawn in relation to another subject. Therefore, the conclusion by analogy, in the most general sense, is the transfer of information from one object to another. "The object, which is the direct object of the study is called the model, and the object, to which the information acquired as a result of the study is transferred, is a sample, original, prototype, etc". On this basis, analogy is defined as the relation between any model and its original prototype; the analogy is the conclusion from the model to the original ${ }^{19}$.

C. Hempel claimed that models whose elements and relationships are connected to the world by what is commonly called compliance rules, should include the following three types of compliance:

- between the way the social world is organized and the way the model describes this world;

- between the apparatus used in the modeling and the conceptual apparatus of the modeled theory;

- between the theory and the social world ${ }^{20}$.

${ }^{17}$ Ibid. C. 38.

${ }^{18}$ Уемов А. И. Аналогия в практике научного исследования. М.: Наука, 1970.

${ }^{19}$ Ibid.

${ }^{20}$ Гемпель К. Г. Логика объяснения. М.: Дом интеллектуальной книги, Русское феноменологическое общество, 1998. С. 56-57. 
Accordingly, we see that modeling is a broader concept that includes conclusions by analogy as its integral part. The analogy implies the correlation between the model already given in one way or another and its (prototype), and the result of the model's study, in this case, is assumed to be known. The concept of the method of modeling includes the construction of the model or finding it in nature. An important stage in the application of the modeling method is the study of the constructed model, obtaining with it all the necessary information and, finally, the transfer of conclusions made towards the model to the original.

During the construction, the study of the model and the transfer of conclusions obtained from the model to its original, the researcher relies on the analogy procedures described above and proceeds with the conformity of the model to the modeled object. Usually, objects fully or partially equivalent to the original in relations interested to the researcher are used as models. In the first case, we are talking about isomorphic models, in the second case homomorphic. Isomorphic models with respect to the original must be endowed with the properties of reflexivity, symmetry, and transitivity ${ }^{21}$. For homomorphic models, symmetry property is not required. Most mathematical models are based not on isomorphism but on homomorphism with respect to the original ${ }^{22}$. "Homomorphism is a kind of systematic abbreviated translation. The original is not only translated into another language but is also abbreviated. What eventually comes out after translation and abbreviation turn out to be systematically evenly compressed in half or one third, or some other proportion of the original. Some details of this abbreviation may be lost, but everything in the original is somehow translated, scaled-down and saved" ${ }^{23}$. In the case of a homomorphic reflection, the purpose of modeling is to implement one or another way for the reflection of state space (parameters or properties) of the studied object onto another space, similar to it. Obviously, the processes of simplifying the original within the limits allowed by conditions of the study have general nature.

From the above interpretation of the model, it is obvious that for the vast majority of political processes only homomorphic models are possible.

${ }^{21}$ Кондаков Н.И. Логический словарь-справочник. Отв. ред. Д.П. Горский. М.: Наука, 1975. С. 191.

22 Ibid. C. 123.

23 Прангишвили И.В. Системные законы и закономерности в электродинамике, природе и обществе. М.: Наука, 2001. 


\section{Assessment of the applicability of different types of models for modeling contemporary political activism}

According to F. Pashchenko, in the framework of the extensive system of modeling methods that exist today, great importance belongs to analytical, experimental and combined methods ${ }^{24}$.

The analytical method implies the imaginary penetration "inside" the object. In this case, the properties of the object, its mathematical description and interrelationships of elements are established by a comprehensive analysis of the phenomena and processes occurring in it, on the basis of known political, economic and social laws and patterns. The undoubted advantage of the analytical method is that it does not require direct contact between the researcher and the object. This means that when using this method, the modeled socio-political structure and corresponding infrastructure may not exist at all. Thus, when using this method on the basis of socio-political description, analytically mathematical model may be built of such a political process, which has certain attributes that interest the researcher, even if it was not yet built in real life. The building of the suchlike model opens up the broadest possibilities for analyzing the various possible situations and ways of development that may take place in the future of a real political process under certain initial conditions.

Determined analytical models are useful as a tool for mathematical experiments aimed at developing a strategy for more detailed cognition of the political process and its subsequent management. Calculations with the use of deterministic, deductive models may be very productive as they replace practically impossible field experiments. At the same time, it should be acknowledged that such models cannot be used for daily monitoring or for a detailed forecast of the real dynamics of political development. This is explained by the need for a clear parameterization of such models, without which they are transformed into beautiful but useless metaphors. Despite the indicated advantages of the analytical method, it should be noted that the extensive experience of modeling complex natural objects, accumulated in various fields of science, shows that, despite its attractiveness, it can have only limited use ${ }^{25}$.

Limited use of the analytical method is associated with its complexity and the need to know the laws and patterns of internal processes of the studied system. Mainly, this requirement may be fulfilled in the frameworks of natural sciences, and therefore can justify itself in the study of the political process only when building cognitive models of a general nature. When studying modern political activism, we are faced not only with the problem of an

${ }^{24}$ Пащенко Ф.Ф. Введение в состоятельные методы моделирования систем : в 2-х ч. М.: Финансы и статистика, 2006. Ч. 1: Математические основы моделирования систем.

${ }^{25}$ Малинецкий Г. Г. Современные проблемы нелинейной динамики. М.: УРСС, 2002. 
insufficient study of the subject but also with the problem of the constant variability of forms and methods of political activism. Moreover, the digital capabilities of the modern era give it additional features and modifications.

Experimental studies are based on obtaining the dependencies by measuring corresponding values directly on the studied object. The essence of the experimental method of modeling implies that in the process of functioning of a real socio-political object the researcher measures the selected parameters and according to the results of observations assesses the properties of the object and make a mathematical description, suitable for the analysis of the state of this object and for the development of optimizing criteria for a given object. The construction of a mathematical model of an object based on experimental studies and measuring of its input and output signals is called object identification ${ }^{26}$. Experimental methods of modeling may be considered more appropriate to describe political activism. At the same time, as in many other cases, it is a difficult problem to determine the degree of impact on society and the political process of some steps made at the actions of political activism.

Combined methods are a combination of analytical and experimental methods for the construction of a mathematical model. If these models are used, the type and structure of the model are selected based on an analytical approach. The structure of the model, in this case, we must take into account the objective laws of the processes occurring in the studied object. Unknown parameters included in the obtained model are determined on the basis of experimental studies. Combined methods usually include expert dynamic and expert analytical methods ${ }^{27}$. The last two approaches are virtually indistinguishable in content and methods. Their main difference unlike these approaches from analytical and experimental is that, in addition to analytical and experimental methods, they use expert knowledge about the system under study - the knowledge of the researcher, expert analyst, deeply familiar with the process being studied or the phenomenon. Such approaches have been widely used in the creation of human-machine systems, decision-making for the management of large-scale systems, industries, regions, nuclear and large thermal power plants, metallurgical, petrochemical and other industries. ${ }^{28}$ There is a double situation in the political sciences, where, on the one hand, there is a long tradition of using expert knowledge, but on the other hand, it is extremely rare that this knowledge is used to build research models.

\footnotetext{
Пресс, 1994

28 Дургарян И.С. Системы поддержки принятия решений в человеко-машинных системах управления. Труды Института проблем управления. 2000. Т. 8.
}

${ }^{26}$ Райбман И.С. Что такое идентификация? М.: Наука, 1970.

${ }^{27}$ Бургин М.С. Введение в современную точную методологию науки. М.: Аспект 
An attempt to combine analytical and expert methods of model construction in the last decades has given rise to the so-called holistic approach to the description of complex systems and models' construction.

A holistic approach implies a global description and is necessary in the case of complex systems where traditional reductionist methods do not allow to fully analyze trends because of an excessively large number of significant variables.

The possibility of a holistic description is associated with the "compression" of information by introducing order parameters. As a rule, holistic models are characterized by "slow" equations that link these parameters to each other. It should be noted that the transition from a reductionist to a holistic approach in the construction of the models means, in fact, a transition from purely deterministic models to phenomenological ones. A bright example of a holistic approach to modeling is, in our opinion, synergetic models.

Synergetics is often associated with the names of H. Haken ${ }^{29}$ and I. Prigogine ${ }^{30}$, and these scholars are called the founders of synergetics, which is quite true. Synergetics is also associated with the names of such scientists as R. Thom, B. Mandelbrot, Yu. Klimontovich, S. Kurdyumov, G. Malynetsky, D. Chernavsky, and others. The term, which has become popular, is being used in the most unexpected and paradoxical contexts: the synergetic paradigm, the synergetic approach to national security, the synergetic beginnings of education, etc.

H. Haken gave one of the first definitions of the subject of synergetics. According to him, synergetics studies systems consisting of a large number of parts, components or subsystems, in a word, of details that interact in a complex way. The word "synergetics" means "joint action", emphasizing the coherence of the functioning of parts, reflected in the behavior of the system as a whole ${ }^{31}$.

Synergetics is interested in the general patterns of evolution of systems of any nature. Abandoning the idea of the specific nature of systems, synergetics find the ability to describe their evolution in an international language, establishing a kind of isomorphism of two phenomena studied by specific means of two different sciences, but having a common model, or, more precisely, being reduced to a common model. Discovering the unity of the model allows synergetics to make advantages of one scientific field accessible to the representatives of another field and transfer the results of one science to the seemingly extraneous environment ${ }^{32}$.

${ }^{29}$ Хакен Г. Тайны природы. Синергетика: учение о взаимодействии. М. : ИКИ, 2003.

${ }^{30}$ Пригожин И. Р. Порядок из хаоса: Новый диалог человека с природой : Пер. с англ. М. : Прогресс, 1986.

${ }^{31}$ Хакен Г. Тайны природы. Синергетика: учение о взаимодействии. М. : ИКИ, 2003.

32 Данилов Ю.А. Роль и место синергетики в современной науке. URL: http://www.synergetic.ru/science/rol-i-mesto-sinergetiki-v-sovremennoy-nauke.html. 
So, according to one of its creators, H. Haken, synergetics is designed to play the role of a kind of meta-science that observes and studies the general nature of those laws and dependencies that some sciences consider "their own". The closest to it in terms of proclaimed tasks is the direction of the study of the general theories of systems, popular in the 50's - 70's of the last century ${ }^{33}$. Unlike the "standard" system approach, synergetics offers a different approach to selecting information about a particular process for analysis and modeling. Instead of a large number of factors (the so-called components of the state vector), on which the state of the system depends on during ordinary finitedifference modeling ${ }^{34}$, synergetics considers a few order parameters on which the components of the state vector of the system depend and which, in turn, influence the order parameters. The transition from the components of the state vector to the few order parameters is the meaning of one of the basic principles of synergetics, the so-called principle of subordination.

The distribution of synergetic concepts as a general scientific paradigm raised the question not only of the expansion of the categorical apparatus of social and humanitarian disciplines but also of the use of some universal mathematical models developed in the framework of the theory of nonlinear dynamic systems and the mathematical theory of chaos. As already mentioned, synergetics proceeds from the fact that, in reality, the "linear nature of the development of processes" and "equilibrium states" are not always dominant.

The complexity and unpredictability of the behavior of systems during periods of their unstable development - bifurcation points - deserves much more attention. The manifestations of such points are quite diverse the destruction of states, external interventions, coups, large-scale terrorist acts, wars, financial and other crises, forced reforms, stalemate electoral situations, revolutions, powerful protest reactions of society. It is in these circumstances that "minor" causes can have a decisive influence on the trajectory of political and international processes.

An important quality of synergetic modeling, which makes it capable of answering questions about the essence of the bifurcation of the domestic political process, can be considered the possibility of establishing the likelihood of chaotic regimes in a long process, including those that will arise "without any noticeable" external reasons, and simply because of the nonlinear process development ${ }^{35}$. In fact, in today's scientific work, the study of political phenomena and processes is dominated by the notion that every single point of bifurcation and the nearest determinative stage of development

\footnotetext{
33 Уемов А.И. Системный подход и общая теория систем. М. : Наука, 1978.

${ }^{34}$ Павловский Ю. Н. Имитационное моделирование. 2-е изд., стер. М. : Издательский центр «Академия», 2008.

35 Див., напр.: Бородкин Л.И. Бифуркации в процессах эволюции природы и общества: общее и особенное в оценке И. Пригожина. Информационный бюллетень Ассоичиации «История и комп ’ютер». 2002. № 29. С. 5-19.
} 
of a large socio-political unit like a state is best matched by a certain parameter of $\operatorname{order}^{36}$. At the same time, there is no unity in the scientific environment as to the method of the most adequate description of the given bifurcation, of the world, and the bifurcations of individual countries under the conditions of this "global" bifurcation (of course within the synergetics, in which, however, many separate directions have appeared), and relatively order parameters for the current bifurcation situation.

The chaos that occurs near the bifurcation point does not mean that the order disappears. Rather, the dynamics of the process become internally unpredictable (not through external factors). The central issue discussed in this connection is the mechanisms of choice of alternatives to social development, the influence of chance, which in bifurcation points are fundamentally impossible to predict and predict in a deterministic sense. It is from this point of view that synergetic modeling is a promising tool for building models of modern activism. At the same time, these models will have a somewhat unusual character: it is recognized that if the sources allow reconstructing the patterns of long-term development of the process, using computerized methods can determine the likelihood of chaotic modes, including those that occur "without any noticeable "external reasons, but simply because of the non-linear process development ${ }^{37}$. Accordingly, when constructing a model of political activism by a synergetic method, it is said that the researcher should parameterize the model not so much by "unique" material of individual political actions, but by aggregated formalized data on the general dynamics of such actions - their number at certain intervals, the number of participants in saturation of flights. and non-political slogans and requirements, the degree of coverage of these actions by the media, etc.

At the same time, the experience of synergetic modeling makes it possible to prove that even at bifurcation points "anything" cannot happen. The number of real-world scenarios is always limited, and if events have already entered one of the modes (trajectories), the system irrevocably changes in the direction of the corresponding end state (attractor) ${ }^{38}$.

A successful example of the synergetic model of political activism is the modified J. Davies' model of J-revolutions, a model of sudden formation of political resistance ${ }^{39}$. The main parameter of order in this model based

${ }^{36}$ Халтурина Д.А. Системный мониторинг: Глобальное и региональное развитие. М.: УРСС, 2010. С. 5.

${ }_{37}^{37}$ Див., напр.: Бородкин Л.И. Бифуркации в процессах эволюции природы и общества: общее и особенное в оценке И. Пригожина. Информационный бюллетень Ассочиачии «История и комп 'ютер». 2002. № 29. С. 5-19.

${ }^{38}$ Назаретян А.П. От будущего - $к$ прошлому (Размышление о методе). Общественные науки и современность. 2000. № 3. С. 148.

${ }^{39}$ Polovyi M. A., Gadzhyieva D. Synergetic modification of J. Davies' model for simulation of "sudden" formation of protest activity. Athenaeum. 2015. Vol. 48. P. 76-89. 
on the assumption about decisive role of worldview and perception of politics by individual and public opinion ${ }^{40}$. Such an interpretation in some way supports the theory of J. Davies. But it seems right to assume that in order to form a political protest activity a stimulating and unifying factor for a diverse population should become public perception of political reality and their own expectations from it. A synergetic order parameter that determines the formation, expansion or, conversely, narrowing, of protest activity in modern political process is the ratio between the perception of current political reality and tactical expectations from it. The dynamics of this order parameter determines the content of protest activity's model we've created ${ }^{41}$.

\section{CONCLUSIONS}

Thus, with the increasing spread of various forms of political activism, its modeling becomes important. Models of political activism should serve to the purposes of short- and medium-term forecasting of the events related to activism.

In theoretical terms, the model of the political process should be understood as an artificially created object in the form of various symbolic constructions, which in some sense is analogous to the studied process. The task of creating a model is its research in order to deepen the knowledge about modeled features of the original object.

To reflect and predict the future state of any element of the political process, different models can be constructed to formalize its various functions. The number of these models often depends on the complexity, specification or simplification of the description of the real system.

There is a variety of methods of model construction, they include analytical, experimental and combined methods. Combined methods are most suitable for modeling of political activism. The combined methods include expert-dynamic and expert-analytical methods. A holistic approach to the modeling of complex systems is closely linked to these methods. Synergetic modeling is a scientific continuation and a formal extension of the holistic approach.

Synergetics offers an almost holistic approach to the selection of information about modeled process: instead of a large number of factors that determine the state of the system in the ordinary simulation, as finitedifference for example, synergetics considers the few order parameters on which the components of the state of the system depend and which in turn affect the order parameters.

${ }^{40}$ Польовий М. А. Політичні процеси: теорія та практика моделювання. Фенікс: Одеса. 2011. С. 190-217.

41 Polovyi M. A., Gadzhyieva D. Synergetic modification of J. Davies' model for simulation of "sudden" formation of protest activity. Athenaeum. 2015. Vol. 48. P. 76-89. 
The synergetic approach is the most promising in modeling the processes of political activism. In constructing a model of political activism with the use of a synergetic method, the researcher must parameterize the model not so much with the "unique" material of particular political actions as with aggregated formalized data on the overall dynamics of such actions.

The model of sudden formation of political resistance - J. Davies' model of J-revolutions modified by the author- is an example of the synergetic model of political activism. It is obvious that synergetic models of political activism are the most optimal and, at the same time, they need further improvement.

\section{SUMMARY}

The article deals with some methodical problems of selection of appropriate modeling techniques for simulation of contemporary forms of political activism in the digital age. The meaning of model and simulation, their connection with the theory, analogy and metaphor have been analyzed. The possibilities for application of homomorphic models have been evaluated. It has been concluded that the vast majority of political processes may be simulated only by homomorphic models. A short overview of the strengths and weaknesses of analytical, experimental and combined methods of building models has been done. It has been established that an attempt of combining analytical and expert methods of building models in recent decades has generated a so-called holistic approach to the description of complex systems. The characteristic of holistic approach has been given. The continuation of the holistic approach in the form of a synergetic approach has been characterized. It has been noted that the synergetic approach involves a global description and is necessary in case of complex systems, where traditional reduction methods do not allow to analyze trends due to an excessively large number of significant variables. Therefore, the synergetic approach is most convenient for the simulation of processes of political activism. 


\section{REFERENCES}

1. Павловский Ю.Н., Белотелов Н.В., Бродский Ю.И. Имитационное моделирование. М. : Издательский центр «Академия», 2008 - 240 с.

2. Моисеев Н.Н. Математика в социальных науках. Математические методы в социологическом исследовании. М., 1981. С. 10-24.

3. Easton D. A Systems Analysis of Political Life. New York: Wiley, 1965.

4. Вартофский М. Модели. Репрезентация и научное понимание. М.: Прогресс, 1988. 506 с.

5. Кондаков Н.И. Логический словарь-справочник / Отв. ред. Д.П. Горский. М.: Наука, 1975. С. 361.

6. Пащенко Ф.Ф. Введение в состоятельные методы моделирования систем : в 2-х ч. М.: Финансы и статистика, 2006. Ч. 1: Математические основы моделирования систем. 328 с.

7. Штофф В.А. Моделирование и философия. Л.: Наука, 1966. C. 9.

8. Бойко-Бойчук Л. Метод аналогій у соціально-політичних дослідженнях. Політичний менеджмент. 2007. № 4. С. 78-80.

9. Уемов А. И. Аналогия в практике научного исследования. М.: Наука, 1970. С. 50.

10. Гемпель К. Г. Логика объяснения. М.: Дом интеллектуальной книги, Русское феноменологическое общество, 1998. С. 56-57.

11. Прангишвили И.В., Пащенко Ф.Ф., Бусыгин Б.П. Системные законы и закономерности в электродинамике, природе и обществе. М.: Наука, 2001.

12. Малинецкий Г. Г., Потапов А.Б. Современные проблемы нелинейной динамики. М.: УРСС, 2002.

13. Райбман И.С. Что такое идентификация? М.: Наука, 1970.

14.Бургин М.С. Введение в современную точную методологию науки. М.: Аспект Пресс, 1994.

15. Дургарян И.С., Пащенко Ф.Ф. Системы поддержки принятия решений в человеко-машинных системах управления. Tруды Института проблем управления. 2000. Т. 8.

16. Хакен Г. Тайны природы. Синергетика: учение о взаимодействии. М. : ИКИ, 2003.

17. Пригожин И. Р., Стенгерс И. Порядок из хаоса: Новый диалог человека с природой : Пер. с англ. М. : Прогресс, 1986.

18. Данилов Ю.А. Роль и место синергетики в современной науке. URL: $\quad$ http://www.synergetic.ru/science/rol-i-mesto-sinergetiki-vsovremennoy-nauke.html.

19. Уемов А.И. Системный подход и общая теория систем. М. : Наука, 1978. 
20. Бородкин Л.И. Бифуркации в процессах эволюции природы и общества: общее и особенное в оценке И. Пригожина. Информационный бюллетень Ассочииаџии «История и комп'ютер». 2002. № 29. С. 5-19.

21. Халтурина Д.А. Системный мониторинг: Глобальное и региональное развитие. М.: УРСС, 2010. С. 5.

22. Назаретян А.П. От будущего - к прошлому (Размышление о методе). Общественные науки и современность. 2000. № 3. С. 148.

23. Polovyi M. A., Gadzhyieva D. Synergetic modification of J. Davies' model for simulation of "sudden" formation of protest activity. Athenaeum. 2015. Vol. 48. P. 76-89.

24. Польовий М. А. Політичні процеси: теорія та практика моделювання. Фенікс: Одеса. 2011. С. 190-217.

\section{Information about the author:}

Poloyi M. A.,

Doctor of Political Sciences, Professor at the Department of Political Science and Public Administration, Vasyl' Stus Donetsk National University 21, 600-richcha str., Vinnitsya, 21001, Ukraine 